\title{
ARTICLES
}

\section{Pathways Across the Valley of Death: Novel Intellectual Property Strategies for Accelerated Drug Discovery}

\author{
Arti K. Rai, J.D., * Jerome H. Reichman, J.D., $†$ Paul F. Uhlir, J.D., $\ddagger$ \\ and Colin Crossman, J.D.§
}

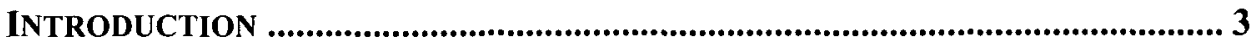

I. Framing the Problem ........................................................................ 7

A. The Dearth of Drugs Against NEw Targets ................................ 8

B. ATTEMPTS To BRIDGE THE PubliC-PRIVATE DividE ............................ 12

II. Models for Multi-Firm, Public-Private Collaboration............. 15

A. EXISTING COLLABORATIONS ON TOXICITY AND EFFICACY ..................... 15

B. EXPANDING THE COLLABORATIVE APPROACH ..................................... 19

\footnotetext{
* Professor of Law, Duke University School of Law; Member, Institute for Genome Sciences and Policy, Duke University. The authors gratefully acknowledge the support of the National Human Genome Research Institute and the Department of Energy under Grant No. 5P50 G003391-02. Earlier versions of this article were presented at Harvard Law School, Northwestern University Law School, and at the Catholic University of Leuven, Belgium. We thank Funmi Arewa, Christopher Austin, Dan Burk, Bob Cook-Deegan, Einer Elhauge, Terry Fisher, Mark Guyer, Regina Herzlinger, Christopher Lipinski, Allen Roses, Geertrui Van Overwalle, and Christen Linke Young for helpful discussions, Derek Tan for his exceptional comments, and Jennifer Giordano-Coltart for exceptional research assistance. We also thank the students in Professor Elhauge's Fall 2006 Health Policy seminar and Professor Arewa's Fall 2007 Intellectual Property seminar for their comments.

${ }^{\dagger}$ Bunyan S. Womble Professor of Law, Duke University School of Law.

$\ddagger$ Director of International Scientific and Technical Information Programs, The National Research Council, Washington D.C. The views expressed here are those of the author and not necessarily those of the National Research Council.

${ }^{\S}$ Faculty Fellow, Duke University School of Law, 2005-2006.
} 
III. THE PROPOSED MULTI-FIRM PARTNERSHIP................................................ 20

A. THE THRESHOLD QUESTION OF OVERLAP ............................................... 21

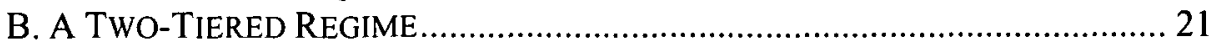

1. TIER 1: BEHIND THE VEIL OF IGNORANCE............................................ 22

2. TIER 2: BEYOND THE VEIL OF IGNORANCE …………............................. 25

C. THE OPTION OF A CONTRACTUALLY-CONSTRUCTED LIABILITY REGIME.. 25

D. ADDING NEW PARTICIPANTS ......................................................... 28

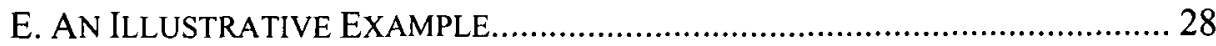

F. SINGLE FIRM PUBLIC-PRIVATE PARTNERSHIPS ......................................... 30

IV. ANALYZING THE COLLABORATION: STAKEHOLDER INCENTIVES AND

TRADEOFFS........................................................................................................ 31

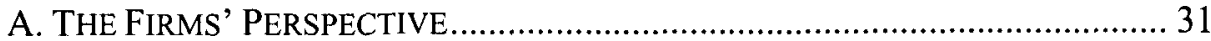

B. THE ACADEMIC RESEARCHERS' PERSPECTIVE .......................................... 32

C. THE PERSPECTIVE OF THE TRUSTED INTERMEDIARY ................................. 33

D. ANTITRUST CONCERNS AND THE PUBLIC INTEREST .................................. 34

CONCLUSION: BROADER IMPLICATIONS OF THE COLLABORATIVE

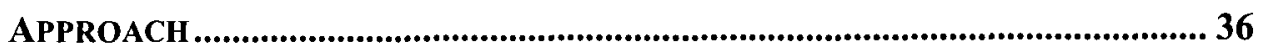




\section{INTRODUCTION}

Most therapeutic interventions produced by pharmaceutical firms take the form of small molecule drugs,' which are mass produced at low marginal cost and ingested orally. Drug therapies typically work by affecting the activity of human proteins, known in the industry as targets, ${ }^{2}$ that have been implicated in disease pathways. Thus far, medical science has identified safe and effective therapies for only a few hundred of the estimated 3000 protein targets in the human genome that are potentially susceptible to a drug. ${ }^{3}$ Moreover, pharmaceutical firms have encountered major obstacles in producing fundamentally new small molecule drugs, especially those that work against new targets. According to one report, an average of only three drugs that act on novel targets have reached the market annually in recent years. ${ }^{4}$

This highly visible problem has attracted commentary in scholarly articles, ${ }^{5}$

1. We use the term "small molecule" to distinguish that class of compounds that can alter the activity of DNA or proteins but are not themselves proteins, peptides, or nucleic acids.

2. Ideally, potential targets would include not only individual proteins but also protein-protein interactions. See Michelle R. Arkin \& James A. Wells, Small-Molecule Inhibitors of ProteinProtein Interactions: Progressing Towards the Dream, 3 NATURE ReVs. DRUG Discovery 301 (2004).

3. Adrian Whitty \& Gnanasambandam Kumaravel, Between a Rock and a Hard Place?, 2 NATURe Chemical BIOlogy 112, 112 (2006) (giving an estimate of about three hundred proteins); Andreas P. Russ \& Stefan Lampel, The Druggable Genome: An Update, 10 DrUg DiscoverY TODAY 1607 (2005). Under the definition used in this Article, susceptibility to a drug, or "druggability," is defined by whether the protein is capable of binding a chemical compound. This definition does not address the question of whether the binding will yield a result that is biologically useful.

4. See Brian P. Zambrowicz \& Arthur T. Sands, Knockouts Model the 100 Best-Selling Drugs-Will They Model the Next 100?, 2 Nature Revs. Drug DisCovery 38, 39 (2003); see also U.S. Gov't Accountability OfFice, New Drug Development: Science, Business, Regulatory, and Intellectual Property Issues Cited as Hampering DRug Development EFFORTS 1 (2006) [hereinafter GAO REPORT], available at http://www.gao.gov/new.items /d0749.pdf (stating that FDA submissions for new chemical molecules have generally declined since 1995, even though industry research and development increased $147 \%$ in inflation-adjusted dollars between 1993 and 2004). New chemical molecules are drugs that differ fundamentally in structure from prior molecules. They are, therefore, the type of drugs that are most likely to be active against new targets (or show substantially increased efficacy against old targets).

5. See, e.g., Iain M. Cockburn, The Changing Structure of the Pharmaceutical Industry, Health AfF., Jan.-Feb. 2004, at 10, 11; Fredric J. Cohen, Macrotrends in Pharmaceutical Innovation, 4 Nature Revs. Drug Discovery 78 (2005); Robert F. Service, Surviving the Blockbuster Syndrome, 203 SCIENCE 1796 (2004) (discussing low numbers of new chemical entities approved in 
government white papers, ${ }^{6}$ and the popular press. ${ }^{7}$ Government agencies, such as the National Institutes of Health, ${ }^{8}$ and industry insiders, ${ }^{9}$ have also recognized that one of the most serious pitfalls involves the difficulty of moving across the so-called "valley of death" that separates upstream research on promising genes, proteins, and biological pathways from downstream drug candidates. For example, an upstream finding that a given protein is differentially expressed in individuals with a particular disease may suggest that the protein merits further investigation. However, much more work (especially medicinal chemistry) is necessary to determine how good a target the protein really is and whether a marketable drug candidate that affects the activity of the protein is likely to be developed.

As industry observers have noted, successfully translating upstream research into potential drugs will require experimentation with new models of research and development (R\&D). ${ }^{10}$ In this Article, we propose one such initiative: intensive, large-scale collaboration between academics, who possess unique skills in designing assays that can identify promising targets, and pharmaceutical firms that hold libraries of potentially useful small molecules as trade secrets, making them largely off limits to these same academic scientists.

As we discuss below, conventional patent-based strategies for commercialization of university research, of the type envisioned by statutes like the BayhDole Act of $1980,{ }^{11}$ are unlikely to foster such intensive collaboration. Moreover, while R\&D alliances between small biotechnology firms and large pharmaceutical companies can perhaps fill some of the collaboration gap, thus far these vertical alliances have not appreciably stimulated productivity in the area of small

recent years).

6. See, e.g., U.S. Food \& Drug Admin., Innovation or Stagnation: Challenge and Opportunity on the Critical Path to New Medical Products (2004), available at http://www.fda.gov/oc/initiatives/criticalpath/whitepaper.pdf.

7. See, e.g., Billion Dollar Pills, ECONOMIST, Jan. 27, 2007, at 69, 70 ("With its traditional approach, Big Pharma is not coming up with new drugs fast enough to fill its pipeline.").

8. See, e.g., Christopher Austin et al., NIH Molecular Libraries Initiative, 306 SCIENCE 1138 (2004); see also GAO REPORT, supra note 4, at 40 (noting importance of "translational medicine" for addressing the drug discovery problem).

9. See, e.g., Christopher A. Lipinski, The Anti-Intellectual Effects of Intellectual Property, 10 CURRENT OPINION IN CHEMICAL BIOLOGY 380 (2006).

10. See, e.g., DataMonitor, Addressing Pharma's R\&D Productivity Crisis: Technical and Strategic Initiatives To Improve Core Drug Discovery Capabilities, http://www.market-researchreport.com/datamonitor/DMHC1960.htm (last visited Nov. 2, 2007) (noting that "[c]ompanies must fundamentally review R\&D business models and exploit new strategies for re-establishing core drug discovery expertise").

11. Bayh-Dole Act of 1980, Pub. L. No. 96-517, 94 Stat. 3015 (codified as amended at 35 U.S.C. $\S \S 200-212(2000))$. 
molecules. ${ }^{12}$ To achieve the goal of inducing more well-trained "eyes" to search chemical space for useful molecules, we need a contract-based platform that makes these molecules broadly available to academic experts without compromising future patents.

The collaborative initiative we propose takes its inspiration from existing horizontal collaborations between pharmaceutical firms, which focus on identifying markers of drug safety and efficacy. However, our proposed effort aims to identify potential drugs that may someday reach the market and generate revenue. We therefore need to define ownership more deliberately than do current collaborations, which focus on information that is generally considered precompetitive at all stages. Although firms would not bring specific patents to the table ex ante (as they do, for example, in most vertical $R \& D$ alliances between smaller biotechnology firms and larger pharmaceutical companies), ${ }^{13}$ future intellectual property rights would nonetheless be suitably allocated among collaborators. ${ }^{14}$ Moreover, unlike existing horizontal collaborations that have focused on safety and efficacy issues, our proposed initiative would deliberately integrate academic scientists as a built-in vertical component.

We situate our proposal in the economic literature that has analyzed transaction costs and incomplete contracting in the context of inter-firm R\&D alli-

12. These alliances have been more successful in increasing productivity in the area of biological macromolecules (a class of specialty drugs known as "biologics") like proteins and large peptides. See Cockburn, supra note 5, at 12, 14; Service, supra note 5, at 1797-98. However, such biologics are expensive to develop and hence quite costly to patients (with prices ranging from thousands to hundreds of thousands of dollars for an annual supply). Moreover, the absence of a generic regime for biologics, see infra note 29 , means that their prices do not decrease to any meaningful extent even after patents expire. See, e.g., Geeta Anand, As Costs Rise, New Medicines Face Pushback, Wall ST. J., Sept. 18, 2007, at A1 (making these points and noting that spending on specialty drugs rose twenty-one percent in 2006, as contrasted with six percent for non-generic, non-specialty (i.e., small molecule) drugs); Geeta Anand, $R x$ for an Industry: As Biotech Drug Prices Surge, U.S. Is Hunting for a Solution, WALL ST. J., Dec. 28, 2005, at Al [hereinafter Anand, $R x$ for an Industry] (noting that spending on specialty drugs represents twenty-five percent of national spending on biopharmaceuticals).

13. D. Gordon Smith, The Exit Structure of Strategic Alliances, 2005 U. ILL. L. REV. 303, 308 $\mathrm{n} .29$ (noting that in a sample of 125 genomics alliances, 113 involved the licensing of intellectual property by smaller technology firms); $c f$. Josh Lerner \& Robert P. Merges, The Control of Technological Alliances: An Empirical Analysis of the Biotechnology Industry, 46 J. INDUST. ECON. 125, 132 (1998) (noting that biotechnology firms with more intellectual property rights exercised more control over the alliance).

14. See generally Oliver Hart, Firms, Contracts, and Financial Structure 29-55 (1995) (discussing the importance of ex ante property rights allocation). Ex ante, the information at issue in our proposal is not patentable. Boilerplate patent law does not allow patents on biochemical inventions of unknown function. See Utility Examination Guidelines, 66 Fed. Reg. 1092, 1097-99 (Jan. 5, 2001). 
ances. ${ }^{15}$ The inter-firm alliance we propose would simultaneously redound to the financial benefit of the pharmaceutical industry and promote the interests of public sector researchers. Most importantly, under our scheme intellectual property would be used creatively to secure efficient pathways across the gap that separates upstream research from downstream products-a gap so economically perilous that it has earned the "valley of death" moniker. ${ }^{16}$ If these arrangements generated a larger number of efficacious drugs, the public at large would become the ultimate beneficiary.

In Part I, we frame the problem and describe some alternative efforts, existing and proposed, to accelerate drug development. In Part II, we examine several new pharmaceutical industry collaborations that provide some precedent for our proposed collaboration. In Part III, we set out our proposed multi-firm collaboration model. Finally, in Part IV, we discuss the perspectives of various stakeholders (e.g., pharmaceutical companies, academic researchers, nonprofit funders), with a view toward finding common ground on which to develop the proposed public-private partnership. We also discuss the possibility of single firm public-private partnerships, which could represent a desirable option if a comparison of pharmaceutical firm libraries showed substantial overlap among

15. See, e.g., Suzanne Majewski \& Dean V. Williamson, Incomplete Contracting and the Structure of R\&D Joint Venture Contracts, in INTELleCtuAl Property AND ENTREPRENEURSHIP 201 (Gary D. Libecap ed., 2004) (arguing that the allocation of property rights in innovation generated by $R \& D$ partners is an important part of contract design, particularly in patent sensitive industries like the biopharmaceutical industry); Rachelle Sampson, The Cost of Misaligned Governance in R\&D Alliances, 20 J.L. ECON. \& ORG. 484 (2004) (finding that alliance governance based on transaction cost arguments substantially improves collaborative benefits). The economic literature on incomplete contracting grows out of the literature on transaction cost economics (TCE). Both literatures emphasize the ex ante and ex post transaction cost challenges that managing uncertain future conditions poses for efficient contracting. Unlike the TCE literature, however, the property rights strand of the incomplete contracting literature tends to stress the role of ex ante property rights allocation. A related literature discusses how the availability of statutory intellectual property rights (typically patent rights) in modular information defines the boundaries of the firm and may also facilitate inter-firm market transactions. See, e.g., ASHISH ARORA ET AL., MARKETS FOR TeChNOlogy: The ECONOMICS OF InNOVATION ANd CORPORATE Strategy (2001); Ashish Arora \& Robert P. Merges, Specialized Supply Firms, Property Rights and Firm Boundaries, 13 InDUs. \& CORP. ChANGE 451 (2004); Dan L. Burk \& Brett H. McDonnell, The Goldilocks Hypothesis: Balancing Intellectual Property Rights at the Boundary of the Firm, 2007 U. ILL. L. REV. 575. This literature is not as directly relevant to our proposal, as we do not purport to alter the statutory standards by which patent rights are granted or propose new statutory rights.

16. Although we focus here on translation of biological research into small molecule drugs, the term "valley of death" is widely used to describe difficulties of market translation across different fields of scientific endeavor. See, e.g., Comm. on Accelerating TeCh Transition, Nat'L Research Council, Accelerating TeChnology Transition: Bridging the. Valley of Death FOR MATERIALS AND PROCESSES IN DEFENSE SYSTEMS (2004). 
them. We conclude by considering briefly antitrust concerns as well as the broader implications of the collaborative framework we construct for small molecule libraries.

\section{Framing The Problem}

Biomedical research in the pharmaceutical industry mainly focuses on small molecule chemical compounds. In contrast with proteins or other biologics, small molecule chemicals are usually mass produced at low marginal cost and are taken orally. ${ }^{17}$ Many pharmaceutical firms own collections, or "libraries," of hundreds of thousands of small molecules that they have either synthesized internally or have purchased from outside vendors. Because the functional attributes of these molecules have not generally been studied in any depth, they typically do not meet even the relatively lax standards for patentability currently applied by the courts. ${ }^{18}$ To protect their investment, firms impose a strict regime of trade secrecy.

In order to test the molecules for biological activity pertaining to disease processes, pharmaceutical firms must screen them against interesting proteins. The experimental protocol under which a target protein is screened is known as an assay. For the past few decades, pharmaceutical firms have been using highthroughput screening (HTS) ${ }^{19}$ of small molecule libraries against assays containing target proteins to identify promising compounds that may lead to patentable drugs. HTS allows researchers to examine the interaction between the subject of the assay and all of the many thousands of small molecules housed in a single library in only a few hours, which vastly increases the scope of potentially useful information available to scientists. However, despite explosive growth in genomic and proteomic information about potential targets, and increasing levels of R\&D spending, ${ }^{20}$ results of the HTS approach have thus far been disappointing. As noted earlier, the production of drugs that work against new targets has been

17. The systemic bioavailability of small molecules tends to be greater as well. Depending on their construction, small molecules may simply diffuse through tissues, whereas proteins must be transported.

18. See generally In re Brana, 51 F.3d 1560, 1565-68 (Fed. Cir. 1995) (finding the patentability requirement of utility met where molecule in question had shown cancer-fighting properties in a mouse model).

19. See Konrad H. Bleicher et al., Hit and Lead Generation: Beyond High-Throughput Screening, 2 Nature Revs. Drug Discovery 369 (2003); W. Patrick Walters \& Mark Namchuk, Designing Screens: How To Make Your Hits a Hit, 2 NATURe Revs. Drug Discovery 259 (2003). The initial mechanical problem presented by high-throughput screening of thousands of chemical compounds was solved by the use of robotic devices. Current state-of-the-art scanners use robotics to test more than one million compounds per day against various assays. See Gretchen Vogel, NIH Gears Up for Chemical Genomics, 304 SCIENCE 1728 (2004).

20. See GAO REPORT, supra note 4. 
particularly difficult. ${ }^{21}$

The pharmaceutical firms' failure to find new drugs has been accompanied by a significant decline in sales revenues on existing drugs. Large pharmaceutical firms have typically generated very high sales revenues (and profits) through patents on so-called blockbuster drugs that they can market to large population segments. Prominent examples of blockbuster drugs include cholesterol-lowering agents, anti-hypertensives, and antidepressants. But patents on many blockbusters are now expiring. ${ }^{22}$ Moreover, insurers are becoming reluctant to pay high prices for so-called "me-too" drugs-new products that represent mere incremental improvements over existing molecules. ${ }^{23}$ In order to maintain profitability, pharmaceutical firms must produce fundamentally new molecules that address new targets and thus represent substantial improvements over existing treatment.

\section{A. The Dearth of Drugs Against New Targets}

Although the genome is estimated to contain at least 3000 druggable targets, only a few hundred proteins are fully validated ${ }^{24}$ in the sense that they are shown to be biologically interesting and also susceptible to regulation by metabolically accessible, non-toxic drugs. Despite the infusion of new information about possible targets, some pharmaceutical companies continue to focus on this group of a few hundred, already validated targets. While this strategy may indicate excessive risk-aversion, the fact that health insurance companies were once willing to

21. See supra note 4 and accompanying text; see also Bleicher, supra note 19 , at 370 ("[D]espite the massive growth in screening compound numbers over the past 15-20 years, no corresponding increase in successfully launched new chemical entities has resulted."). See generally U.S. FOOD \& DRUG ADMIN., supra note 6.

22. See Adam Smith, Generic Drug Flood Headed Our Way, CNN Money, Aug. 3, 2005, http://money.cnn.com/2005/08/03/news/fortune500/generic/ (quoting drug industry analyst Andrew Forman of W.R. Hambrecht \& Co. for the proposition that $\$ 100$ billion worth of brand name drugs will lose patent protection between 2006 and 2010).

23. In 2005, sixty-eight percent of employers who provided insurance reported using tiered programs of co-payment to encourage the purchase of inexpensive pharmaceuticals (either generics or brand name drugs on which discounts had been negotiated). David Blumenthal, EmployerSponsored Insurance-Riding the Health Care Tiger, 355 NEw ENG. J. MED. 195, 199 (2006). Historically, the market signals sent to pharmaceutical firms have been less than efficient. Not only have health care payers generally been reluctant to use cost-effectiveness analysis in determining coverage, but the information necessary for determining cost-effectiveness-a public good-has been undersupplied. Jerry Avorn, Sending Pharma Better Signals, 309 SCIENCE 669 (2005). However, this situation may be changing. See id. Moreover, at least in some cases, incremental improvements may not even be patentable. See, e.g., Pfizer v. Apotex, 480 F.3d 1348 (Fed. Cir. 2007) (holding that a new salt form of an existing chemical compound was not patentable).

24. See Whitty \& Kumaravel, supra note 3. 
pay high prices for me-too drugs remains a factor. Validating new targets is also more risky and complex now than in the past. Many observers believe most of the "low hanging fruit"- that is, targets that can be readily modulated by welltolerated, simple chemicals - has been found. This tendency to focus on a small number of known targets means that insufficient research has been undertaken on new targets. ${ }^{25}$

A number of discovery-oriented pharmaceutical firms continue to engage in target validation using in-house biological and chemical expertise. So do some small biotechnology firms. For the latter, patents on new targets can serve as the basis for both arms-length licensing and more vertically integrated R\&D alliances with pharmaceutical firms. One empirical study indicates that biotechnology and pharmaceutical firms formed more than 1000 such two-firm alliances between 1993 and $2000 .^{26}$ Despite these alliances, which may be responsible for a growing pool of therapeutics that are biological macromolecules, ${ }^{27}$ very few new small molecule drugs have emerged. ${ }^{28}$ Given escalating health care expenditures, this dearth of cost-effective small molecules, which (unlike biologics) can be made at low marginal cost after relevant patents expire, ${ }^{29}$ is particularly unfortunate.

Moreover, while biotechnology firms could previously use early stage patents to secure venture capital funding or form vertical alliances, such patents no longer guarantee either funding or an alliance. Industry analysts have recently emphasized the biomedical "funding gap" resulting from the increasing reluc-

25. See, e.g., Cockburn, supra note 5, at 12. It is theoretically possible that the low-hanging fruit that has already been found represents the sum total of biological targets on which research is justified as an economic matter. In other words, the costs of doing further research may exceed the health benefits achieved by any new drugs that might be found. There is little evidence to back this hypothesis, however.

26. Matthew J. Higgins, The Allocation of Control Rights in Pharmaceutical Alliances (Soc. Sci. Research Network, Working Paper No. 918980, 2006), available at http://ssrn.com/abstract= 918980 (describing an empirical study using data from Recombinant Capital, a California-based biotechnology consulting firm). For a discussion of such licensing and alliance activity at one of its historical spikes (around 2000-2001) see Arti K. Rai, Fostering Cumulative Innovation in the Biopharmaceutical Industry, 16 BERKELEY TECH. L.J. 813, 815-18 (2001).

27. See Anand, Rx for an Industry, supra note 12 (noting the twenty-five percent market share now held by specialty drugs, primarily biologics).

28. See GAO REPORT, supra note 4.

29. Currently, there is no generic biologics regime. Moreover, even if a generic biologics regime were established, bioequivalence is likely to be harder to prove in the context of biologics than in the context of small molecules. In any given case, the FDA may require clinical trials to demonstrate comparable safety and efficacy. This will create a barrier to entry for generic competitors. See Henry Grabowski et al., Entry and Competition in Generic Biologics, 28 Managerial \& DeCISION ECON. 439 (2007). 
tance of venture capital and pharmaceutical firms to invest far upstream. ${ }^{30}$

The failure of efforts to fill the small molecule pipeline may prove to be a transient phenomenon, particularly if the integration of information technology accelerates drug development efforts. However, despite optimistic predictions in the past, ${ }^{31}$ information technology has not yet yielded significant efficiencies. This failure makes experimentation with supplementary approaches imperative.

Another candidate for undertaking financially risky target validation is academia. Indeed, a key economic argument for public funding of science is that the private sector will tend to undersupply research with uncertain commercial potential. ${ }^{32}$ Even though it may need some assistance in identifying which targets are most likely to bind drug-like molecules, the academic sector generally possesses the combination of skills needed for assay development. ${ }^{33}$ But most academics have lacked systematic access to high-throughput screening and to the small molecule libraries necessary for comprehensive target validation. Instead, academics who desire access to small molecules in a pharmaceutical firm's library must negotiate terms of access and the corresponding intellectual property considerations on an ad hoc basis. Knowledgeable observers have long suggested that the transaction costs associated with these individualized negotiations constitute a significant barrier. ${ }^{34}$

A recent survey of 414 academic scientists by John Walsh, Charlene Cho, and Wesley Cohen provides some evidence of the magnitude of these costs. In general, academic scientists report that negotiations between industry and academia concerning materials are likely to take longer, and cause more delay, than negotiations within academia: thirty-five percent of such negotiations require more than a month (as contrasted with twenty-one percent of negotiations with university suppliers) and sixteen percent of such negotiations result in a research delay of over one month (as contrasted with six percent of academic negotia-

30. See, e.g., Arthur Klausner, Mind the (Biomedical Funding) Gap, 23 NATURE BIOTECHNOLOGY 1217 (2005) (tracking the history of funding for research, and noting the reluctance of venture capital firms to fund upstream biomedical ventures).

${ }^{31}$ One of the authors of this Article previously made some optimistic predictions in this regard. Arti K. Rai, The Information Revolution Reaches Pharmaceuticals: Balancing Innovation Incentives, Cost, and Access in the Post-Genomics Era, 2001 U. ILL. L. REV. 173.

32. See Kenneth Arrow, Economic Welfare and the Allocation of Resources for Invention, in The Rate AND Direction OF INVEnTIVE ACTIVITY 609 (Richard R. Nelson ed., 1962) (discussing problems of uncertainty, indivisibility, and lack of appropriability involved in the production of information).

33. See Adrian J. Ivinson, Letter to the Editor, University Investment in Drug Discovery, 310 SCIENCE 777 (2005) (contending that academics have been underutilized in drug research and discovery).

34. See Lipinski, supra note 9 , at 382 (discussing individualized negotiations between principal investigators and pharmaceutical firms). 
tions). ${ }^{35}$ Where the material in question is a drug, the transaction becomes particularly arduous. All other factors being equal, an academic's request for a drug (whether from industry or from another academic) was one-twelfth as likely to be fulfilled as requests for other materials. ${ }^{36}$

Strains in academic-industry negotiations concerning drug-related materials should come as no surprise. Such negotiations would typically become an option only in cases where the firm's research on a drug compound had progressed to the point of disclosure through publication (and associated patenting). ${ }^{37}$ Disclosure would serve to alert the academic researcher that a firm had discovered a promising compound. At that stage, much would be known about the drug compound, which would make the resulting transactions of relatively high value. The firm would probably demand significant compensation for transferring the drug. In fact, empirical data indicates that seventy percent of agreements involving the transfer of drugs to academics include reach-through rights on improvements. ${ }^{38}$

At some point, industry requests for reach-through rights in patented drugs may become routine. As matters currently stand, however, academics and university technology transfer officers remain uncertain about the appropriate use of such rights, ${ }^{39}$ and their uncertainty can lead to impasse. The fact that seventy percent of agreements to transfer drugs to academics also include some restrictions on publication ${ }^{40}$ no doubt exacerbates difficulties in negotiation.

Of course, information could flow in the opposite direction. Firms do monitor academic publications to determine whether researchers are working on promising targets. In some cases they successfully form partnerships with the academics in question. ${ }^{41}$ But surmounting difficulties in negotiation across the

35. John P. Walsh et al., Where Excludability Matters: Material Versus Intellectual Property in Academic Biomedical Research, 36 RESEARCH POLICY 1184, $1185-87$ (2007).

36. Id. at 1190-91. When reporting this statistic, the authors do not control for whether the supplier is an academic or is in industry. Thus it is not possible to determine whether requests for drugs were less likely to be fulfilled by industry suppliers than academic suppliers.

37. Cf. Lipinski, supra note 9 , at 381 (discussing circumstances where a firm refers to a compound in a peer reviewed publication). In order to preserve commercial value, the firm would presumably allow publications about the compound only after a relevant patent application had been filed.

38. Walsh et al., supra note 35 , at 1193 . A reach-through royalty is an industry term that refers to a royalty that extends beyond the licensed item to products made using the licensed item.

39. See Rebecca S. Eisenberg, Bargaining Over the Transfer of Proprietary Research Tools, in EXPanding the Boundaries of INTEllectual Property 223 (Rochelle Cooper Dreyfuss et al. eds., 2001). It is also noteworthy that while academics often ignore patents on research materials and make the materials in-house if they have the ability to do so, drug patents represent a prominent exception. See Walsh et al., supra note 35, at 1192. In the case of drugs, both lack of in-house expertise and patents represent barriers to use. Id.

40. Walsh et al., supra note 35, at 1193.

41. Telephone Interview with Allen Roses, Senior Vice President of Pharmacogenetics, 
academic-industry divide appears challenging in this context as well. In the survey by Walsh and his colleagues, academic respondents admitted to failing to fulfill thirty-one percent of requests for materials from industry (as contrasted with only six percent from other academics). ${ }^{42}$

\section{B. Attempts To Bridge the Public-Private Divide}

More standardized legal documentation is one obvious mechanism for reducing transaction costs in transfers of drug-related materials between the private sector and academics. In general, standardized contracts can produce positive externalities that reduce transaction costs for users, ${ }^{43}$ and efforts in this direction could be helpful. However, because the transactions in question are likely to be of high value, full standardization will be difficult to achieve, or even affirmatively undesirable. Significant benefits may accrue from some level of customization. Moreover, the creation of standardized agreements represents a collective action problem. ${ }^{44}$ Given the divergent perspectives of academia and the private sector, solving this problem may not be straightforward. ${ }^{45}$

Even if standardized agreements were successfully created and implemented, the universe of transactions would be limited to those circumstances in which significant work had already been carried out. Drug discovery might be accelerated, but only to a limited extent. To put the point another way, the problem is only partly one of transaction costs in instances where transactions might currently occur. More fundamentally, under the existing regime, insufficient numbers of transactions--specifically, screens of potentially interesting assays against large volumes of small molecules-occur in the first instance.

A more comprehensive response to the "valley of death" problem is the Molecular Libraries Initiative (MLI), undertaken by the National Institutes of Health (NIH) several years ago. ${ }^{46}$ Although the purposes of the MLI go beyond target

GlaxoSmithKline, in Research Triangle Park, N.C. (Apr. 18, 2006) [hereinafter Roses Interview] (discussing partnerships that firms sometimes form upon reading of interesting work by academic researchers).

42. Walsh et al., supra note 35 , at 1191.

43. See Marcel Kahan \& Michael Klausner, Standardization and Innovation in Corporate Contracting (or "The Economics of Boilerplate"), 83 VA. L. REv. 713, 720-30 (1997) (discussing learning benefits conferred on later users and "network benefits" conferred on contemporaneous users).

44. Id. at 736-40 (discussing "coordination" problems).

45. In some cases, implementation of standardized agreements can also represent a collective action problem. See Arti K. Rai \& Rebecca S. Eisenberg, Bayh-Dole Reform and the Progress of Biomedicine, 66 LAW \& CONTEMP. PROBS. 289, 306 (2003) (discussing failure of collective action in university implementation of the standardized Uniform Biological Materials Transfer Agreement).

46. See generally Austin et al., supra note 8 (describing the background and goals of the MLI). 
validation, one key goal is to use public funding to advance research on targets to a stage that would elicit industry interest. The MLI reflects NIH's recognition of three key technological changes: first, that recent research in genomics (e.g., the Human Genome Project) has produced many new potential drug targets; second, that enormous increases in high-throughput screening power make the screening of hundreds of thousands of molecules a day possible for academic centers; and third, that academic centers now have the capacity to efficiently synthesize large numbers of chemical molecules. ${ }^{47}$

The MLI has created a "Molecular Libraries Small Molecule Repository" at the San Francisco facilities of Discovery Partners International. ${ }^{48}$ It has been paying, and will continue to pay, academic researchers with expertise in medicinal chemistry to generate molecules to populate this public domain repository. ${ }^{49} \mathrm{Cur}$ rently, the repository contains about 100,000 small molecules (some of which may duplicate molecules held in pharmaceutical firm libraries). This repository consists of four molecular classes: "specialty sets," including compounds with known biological activity, such as drugs and toxins; natural products; "targeted libraries" for specific, high-profile proteins; and diversity compounds. ${ }^{50}$ Ten academic centers have received funding to use this repository to perform highthroughput screening on assays submitted by the research community. ${ }^{51}$

The assays pertinent to this effort encompass more than simply proteins that are potential drug targets. ${ }^{52}$ As NIH recognizes, small molecules available in the public domain for all researchers are likely to be extremely valuable as research tools that will further basic understanding of biological pathways not necessarily related to direct drug development. Nevertheless, one of NIH's goals is to encourage target validation, so as to narrow the gap between academic outputs and commercial investment and produce more breakthrough drugs. ${ }^{53}$

47. See Nat'l Insts. Health, Overview, Molecular Libraries and Imaging, http://nihroadmap. nih.gov/molecularlibraries/ (last visited Oct. 30, 2007). In addition to the MLI, various individual public institutions offer some HTS capability. For a list, see Solomon Nwaka \& Alan Hudson, Innovative Lead Discovery Strategies for Tropical Diseases, 5 NATURE REvS. DRUg DISCOVERY 941, 947 (2006). However, the MLI is the most ambitious effort.

48. Molecular Libraries Initiative, General Information, http://mli.nih.gov/mlsmr/generalinformation (last visited Oct. 30, 2007).

49. Id.

50. NIH Molecular Libraries, A Roadmap Initiative, MLSMR Project, http://mlsmr.glpg.com/ MLSMR_HomePage/identify.html (last visited Oct. 30, 2007). Targeted libraries include modulators of prominent protein families, such as proteases, kinases, ion channel proteins, and nuclear receptor sets. Diversity compounds include all other compounds. Id.

51. Nat'l Insts. Health, New Paradigm Will Help Identify Leads for Drug Discovery, http://www.nih.gov/news/pr/july2006/nhgri-24.htm (last visited Oct. 30, 2007).

52. Other assays will include "protein-protein interactions, splicing events, and diverse cellular and even organismal phenotypes." Austin et al., supra note 8, at 1139.

53. Id. at 1138 (noting goal of target validation). 
In assessing the more directed goal of generating validated targets, it is important to recognize that the molecules in the public repository are likely to be of lower quality (in terms of target specificity, metabolic attributes, toxicity and other relevant features) than those held by pharmaceutical firms. Although academics and the public sector more generally are beginning to achieve some expertise in medicinal chemistry, ${ }^{54}$ they still do not possess the level of expertise available in the pharmaceutical industry. This handicap may make the MLI target validation goal harder to attain. More comprehensive validation may await confirmation by a private firm's screening against a more "drug-like" molecule in its own library.

One might argue that private firms should be willing to undertake this additional work. Under the default rules of the Bayh-Dole Act of 1980 (which gave universities broad discretion to secure patents on federally funded research), ${ }^{55}$ as well as NIH rules specific to the MLI program, ${ }^{56}$ universities may patent targets or associated assays. Thus, following the conventional vision of Bayh-Dole, ${ }^{57}$ a private firm might hedge the risk involved in this additional work by obtaining an exclusive license to the patented target or assay. However, given venture capitalists' current reluctance to invest in relatively early-stage patents, ${ }^{58}$ these exclusive licenses may not suffice.

In any event, experimentation with another alternative-direct screening of academic assays against a pool of the small molecule libraries held by pharmaceutical firms - would eliminate some unnecessary intermediate work and could also reduce the transaction costs associated with licensing targets. To the extent that such a pool encompassed distinct contributions from several firms, ${ }^{59}$ it might

54. Thus, it appears that the NIH Chemical Genomics Center, which is part of the MLI, has identified three classes of molecules that might be useful in treating Gaucher's disease and is currently working on optimizing their activity and reducing toxicity. See Press Release, Nat'l Insts. Health, Novel Approach Targets an Inherited Disorder: NIH Chemical Genomics Center Jumpstarts Drug Development in Public Sector (July 23, 2007), available at http://www.genome.gov/2552214. In addition, according to Center director Chris Austin, the Center's specific use of quantitative high-throughput screening techniques, which allows chemical compounds to be tested at different concentrations, is likely to reduce false positives and false negatives. Id.

55. Bayh-Dole Act of 1980, Pub. L. No. 96-517, 94 Stat. 3015 (codified as amended at 35 U.S.C. $\$ \S 200-212(2000))$.

56. See NIH MLSCN Project Team Position on Data Sharing and IP in the MLSCN Program (Oct. 15, 2005) (on file with authors).

57. See, e.g., Rebecca S. Eisenberg, Public Research and Private Development: Patents and Technology Transfer in Government-Sponsored Research, 82 VA. L. REV. 1663, 1698-99 (1996) (discussing motivations behind the Bayh-Dole Act); Arti K. Rai, Regulating Scientific Research, Intellectual Property Rights and the Norms of Science, 94 Nw. U. L. REV. 77, 95-97 (1999).

58. See supra text accompanying notes 30.

59. For a discussion of questions regarding overlap in molecular library contents, see infra Section III.A. 
contain considerably more molecules than the current group of 100,000 held in the public-domain repository.

In sum, the impasse in genomic science presents the following underlying characteristics. First, too few qualified researchers are able to use screening assays against the small molecule libraries held as trade secrets by discoveryoriented pharmaceutical firms. ${ }^{60}$ In particular, academic scientists with the talent to design assays lack access to these libraries. Second, to the extent that the libraries held by individual, discovery-oriented pharmaceutical firms differ from each other, it would be advantageous for academics to conduct screening assays against a pool that contains portions of all the libraries held by discoveryoriented firms. ${ }^{61}$

If such a pool were created, it is unlikely that pharmaceutical firms would contribute molecules about which they already possessed significant information (let alone molecules they considered potential lead compounds). Even so, a pool that included some substantial subset of pharmaceutical firms' compounds-for example, "diversity" compounds about which little was known-could prove extremely useful.

\section{Models For Multi-Firm, PUbliC-Private COllaboration}

As a supplement to current approaches such as the MLI and to possible future efforts, including standardized contracts, we suggest a novel, large-scale public-private model. This collaborative approach would draw upon some recent experimentation that pharmaceutical firms are already conducting in this area. Moreover, it would respond to the advice that analysts have been giving the pharmaceutical industry for years-that it must "fundamentally review [its] R\&D business models." ${ }^{12}$ In this Part, we describe inter-firm, public-private collaborations in the areas of safety and efficacy upon which our proposed approach would draw. Part III describes our proposed collaboration in detail.

\section{A. Existing Collaborations on Toxicity and Efficacy}

Until recently, pharmaceutical companies paid insufficient attention to optimizing particular characteristics of small molecules, such as toxicity and "pharmacokinetics" (i.e., absorption, diffusion, metabolism, and excretion), which are

60. Our research suggests that pharmaceutical firms may conduct fewer than one hundred screens per year against their whole library. See Roses Interview, supra note 41.

61. Molecule libraries held by firms that do not seek to discover new targets would be much less useful, as those libraries would primarily contain molecules that work against existing, already validated targets.

62. DataMonitor, supra note 10. 
important for drug safety and efficacy in the human body. ${ }^{63}$ For example, firms sometimes designated a "lead" compound, and assembled a full team around it, solely because the compound had shown significant activity (affinity and selectivity) in a high-throughput laboratory screen against an assay containing a target protein. ${ }^{64}$ Thus, firms were making a substantial investment without any good information about how the body would respond to the potential drug. In recent years, analysts have recognized that the lack of early attention to pharmacokinetic and toxicity-related characteristics of proposed small molecules was a factor in the growing number of pipeline failures, including costly failures at late stages of clinical testing or even after FDA approval for commercial marketing. ${ }^{65}$

Pharmaceutical firms have worked diligently to address this problem. As an initial matter, they purged their libraries of molecules that are likely to be "grit"-for example, molecules that are non-selective inhibitors of many different targets or that have well-known pharmacokinetic or toxicological liabilities. ${ }^{66}$ Firms are also enhancing the quality of their libraries with the help of specialized suppliers of small molecules. Moreover, prior to selecting lead compounds for optimization, pharmaceutical firms have been supplementing high-throughput screening with another stage of focused inquiry into properties necessary for safety and efficacy in the human body. ${ }^{67}$

The pharmaceutical industry is also advancing safety and efficacy goals by means of public-private collaborative partnerships. Specifically, in establishing at least two such consortia, firms have recognized that an optimal level of inquiry into safety or efficacy may require knowledge not contained within the boundaries of a single firm. To the extent that any participating pharmaceutical firm finds standard, early biological signs (also known as biomarkers) of drug toxicity or efficacy, all the other firms in the consortium could use this information for a variety of efficiency-enhancing functions.

For example, biomarkers might help to provide expedited preclinical drug safety evaluation as well as early indicators of clinical safety and efficacy. ${ }^{68}$ They

63. See GAO REPORT, supra note 4 , at 87 (finding that failure rates in human clinical trials based on lack of safety or efficacy were eighty-two percent in the 1996-99 period and ninety-one percent in the 2000-03 period).

64. Bleicher et al, supra note 19, at 370 ("It was not uncommon for a single [hit] compound to be considered a 'lead' structure.").

65. Id.

66. Telephone Interview with Allen Roses, Senior Vice President of Pharmacogenetics, GlaxoSmithKline, in Research Triangle Park, N.C. (Dec. 19, 2006) (on file with authors). See also Lipinski, supra note 9, at 381 (discussing the use of the Lipinski "rule of 5" to filter out compounds that are unlikely to be absorbed orally).

67. See Andrew L. Hopkins, Michael J. Witty \& Solomon Nwaka, Mission Possible, 449 NATURE 166, 168 fig. (2007) (discussing steps such as cell-based or animal model testing).

68. See, e.g., Toxicogenomic Cross-Validation Consortium Agreement $\$ 2.1$ (Jan. 20, 2006) 
could also be used to troubleshoot compounds that fail preclinical drug safety testing. ${ }^{69}$ Whenever the Food and Drug Administration approved a particular biomarker as a reliable indicator of safety or efficacy for a variety of drugs, it might become an industry standard around which all competing firms could converge. As the National Academy of Sciences noted in a recent report endorsing horizontal biomarker consortia, these "precompetitive projects (most likely unrelated to a particular drug) would be enabling to the field.",70

In one recently formed collaboration, the Predictive Safety Testing Consortium (PSTC), all of the major pharmaceutical firms have committed to sharing internally-developed laboratory methods that predict the safety of new treatments. ${ }^{71}$ They have also committed to performing validation experiments on laboratory methods developed by other consortium members. ${ }^{72}$ As a result, under the PSTC, experts from multiple firms work on sequential phases of the same project to develop tests of drug safety.

The PSTC agreement relies heavily on a non-profit, trusted intermediary, Critical Path, of which the FDA is a founding member. Critical Path is responsible for consortium management. For example, it collects membership fees from pharmaceutical firm participants, coordinates the selection of research projects, and (with the assistance of an advisory committee composed of Critical Path and pharmaceutical firm representatives) manages the flow of any confidential information. ${ }^{73}$ If the PSTC advisory committee deems it appropriate to seek patents on technology generated by the consortium, Critical Path will own the patent rights. $^{74}$

(on file with authors) [hereinafter Consortium Agreement] (discussing the use of "safety biomarkers" for expediting preclinical and clinical drug development).

69. See id. \& 2.1(c) (discussing such troubleshooting).

70. Nat'l ACad. of Scis., Cancer Biomarkers: The Promises and Challenges of IMPROVING DETECTION AND TREATMENT 6 (2007), available at http://books.nap.edu/catalog/ 11892.html.

71. Consortium Agreement, supra note 68, $\S 3.2$ (stating that members "must be willing and able to contribute one or more nominated exploratory Safety Biomarkers or other information or Materials for use in Consortium research activities"). Note that the Predictive Safety Testing Consortium was formerly known as the Toxicogenomic Cross-Validation Consortium.

72. See id. (stating that members must "perform validation work with respect to one or more Safety Biomarkers ... and have the capability to cross-validate Safety Biomarkers").

73. See id. $\S 5.2,6.1$ (discussing various aspects of Critical Path's management role).

74. See id. $\S 8.2$ (a) (noting the role of the advisory committee in determining whether to pursue formal patent rights); id. $\S 8.2$ (b) (stating that "[e]ach Member performing any activities under a Research Project hereby assigns to C-Path all of such Member's right, title, and interest in and to any and all Consortium Technology"). The PSTC recently submitted twenty-three proposed biomarkers that could be used to identify kidney toxicity in preclinical animal testing. See Bernadette Toner, Predictive Safety Testing Consortium Submits First Biomarkers to FDA for Qualification, GenOME Web Dally News, June 21, 2007, http://www.genomeweb.com/issues/news/140703- 
While the PSTC focuses on tests for safety, the recently-formed Biomarkers Consortium aims to encompass research that identifies good biomarkers of both drug safety and efficacy. ${ }^{75}$ Like the PSTC, the Biomarkers Consortium includes all of the major pharmaceutical firms, and it allows scientists at competing firms to contribute their expertise to the development of specific biomarkers. As with the PSTC, public sector agencies-most prominently the non-profit Foundation for the NIH, which manages public-private partnerships for NIH-play a major role in selecting research projects and in managing the flow of funding. ${ }^{76}$

Research on biomarkers will ultimately yield products, such as safety assays, that are beneficial to multiple pharmaceutical firms, but are unlikely to represent a core product for any firm. For this and other reasons, both of these consortia require ex ante commitments to relatively liberal licensing agreements for any intellectual property their common efforts may generate.

In the case of the PSTC, members agree that the objective of the consortium is to achieve "broad public dissemination of the results of the research and development projects conducted pursuant to this Agreement." sought only in cases where the advisory committee determines that they would promote dissemination of discoveries. ${ }^{78}$ Moreover, Critical Path is obligated to license any patents it may own to all comers on commercially reasonable terms. ${ }^{79}$

In contrast with the PSTC, the Biomarkers Consortium does not assign intellectual property rights to a trusted intermediary. Rather, inventorship is governed by the default rules of U.S. law, and ownership is defined by the policies of the inventor's employer. ${ }^{80}$ Nonetheless, for all new data and inventions arising out of a particular project, all participants that have an ownership interest in the intellec-

1.htm. It is unclear whether any patent rights have been sought.

75. Press Release, Foundation for the NIH, Public-Private Partnership Forms the Biomarkers Consortium To Advance the Science of Personalized Medicine (Oct. 5, 2006), available at http://www.fnih.org/news/TBC_Press_Release.shtml (noting that "the FDA can use biomarkers to determine whether drugs can safely and effectively treat disease"). The Biomarkers Consortium also plans to identify biomarkers for early disease detection. See id. That research goal is not directly relevant here.

76. See Found. for the NiH, The Biomarkers Consortium, Two-Phased Project Approval Process: Concept Clearance and Project Plan Approval 3 (2006), available at http://test.fnih.org/Biomarkers\%20Consortium/Project_Clearance.pdf (showing a flowchart that details responsibilities of the FNIH Board). While the PSTC funds its research projects from membership fees, the Biomarkers Consortium agreement requires the Foundation for the NIH to seek specific funding for each new project. Id.

77. Consortium Agreement, supra note 68, § 8.2(a).

78. See id.

79. Id. § 8.3(b).

80. Found. For the NIH, The Biomarkers Consortium, General INTEllectual Property And Data Sharing Principles 5 (2006), available at http://test.fnih.org/Biomarkers\% 20Consortium/IP_Policies.pdf. 
tual property generated must grant to all other participants a "non-exclusive, remuneration-free license." 81

\section{B. Expanding the Collaborative Approach}

The formation of collaborative horizontal partnerships to address safety and efficacy raises the question of whether other, somewhat analogous, but more ambitious forms of collaboration could successfully address problems of translation. Specifically, we ask whether large-scale collaboration might improve translation by the academic sector of large volumes of upstream biological information into "validated targets" and potential drug candidates that would be of interest to industry. Like safety and efficacy, translation arguably entails further improvement of relatively undifferentiated trade secret information held by multiple firms. This improvement process may be greatly enhanced through evaluation by multiple parties.

Like the PSTC and the Biomarkers Consortium, our proposed partnership would use a trusted intermediary to facilitate firm participation. Additionally, like the Biomarkers Consortium, it could use the lure of public funding to stimulate greater participation by the private sector. Unlike these other consortia, however, our partnership would produce outputs - potential drug candidates - that engender fierce inter-firm competition. Thus, while the PSTC does not link inventive contribution and ownership, our proposal would maintain a tight link between the two. Additionally, whereas the PSTC and the Biomarkers Consortium mandate relatively liberal licensing practices, our proposal would have no such mandate.

In our proposed partnership, the trusted intermediary would necessarily play a more vigorous role in handling confidential information. As discussed further in Part III, the intermediary would itself conduct the high-throughput screening of the pharmaceutical firms' molecules against assays contributed by academics. It would thus be the only party to the collaboration that possessed full knowledge of all of the assays and molecules that academics and pharmaceutical firms, respectively, had contributed.

By merging academic talent in assay design with the high-quality but underutilized research resource represented by the pharmaceutical firms' libraries, our proposed public-private partnership aims to help the parties traverse the valley of death that currently impedes research on drugs that address new targets. As contrasted with the alternative of complete vertical integration-for example, subsidizing discovery-oriented pharmaceutical firms to hire academics with assay design skills - the public-private partnership we envision would allow assay designers access not simply to one firm's library but instead to a larger, pooled library consisting of small molecule collections that a number of firms had contributed. Unlike complete vertical integration, a public-private collaboration

81. Id. 
would not require academics to change career paths, which would make it more likely to succeed. Pharmaceutical companies contributing portions of their libraries might still be subsidized to the extent that the trusted intermediary consented, at least initially, to bear some of the costs associated with establishing the pool and of providing academic researchers relevant grants.

Pharmaceutical firms that contributed compounds to the pool would profit directly from any commercial drug that emerged from molecules they contributed. As we discuss in Part III, ordinary patent rules would deliver this result. Additionally, participating firms might find it in their interest to allow those who contributed molecules to the pool to receive a small share of the patentee's profits when one or more of their molecules fell within a subset of initially promising molecules identified by the screening process. In the latter instance, profit would be derived from a predetermined royalty stream to the contributing firms under an automatic license, as discussed in Section III.B below.

\section{The Proposed MUlti-Firm PARTNERShIP}

In this Part, we outline the institutional framework and intellectual property strategies that could help stakeholders in both the private and public sectors to make better and more productive use of the aggregate stock of small molecules available for high-throughput screening. These proposals attempt to bridge the gap between patents and the public domain, which is currently regulated only by the application of trade secret law (or actual secrecy), to the private sector's large hoards of small molecules.

The ultimate objectives of our approach are to:

1) Create a research regime in which qualified public-sector participants explore a larger and higher quality pool of molecules than is currently possible.

2) Design a contractually-constructed framework in which publicly funded university research could identify potential lead compounds without compromising patents on those compounds.

3) Administer this voluntarily-adopted framework within a publicprivate partnership that would more effectively translate upstream research into truly innovative therapeutic advances, thereby contributing to overall public health. 


\section{A. The Threshold Question of Overlap}

An initial question regarding pool formation concerns possible overlap among molecules that participating firms may contribute. If, for example, it turned out that molecules contributed by different firms were substantially identical, then there would be little reason to pool the molecules. In that case, a model of multiple public-private partnerships, each built around contracts with a single firm, would become preferable. This alternative model is discussed in Section III.F below.

Because libraries are held by firms as trade secrets, the amount of overlap among them is currently unknown. More important for present purposes, it is unclear whether the molecules actually selected and contributed by participating firms would overlap. Even if we postulate that most firms would contribute socalled "diversity" molecules (because these were the molecules about which they had little specific information), the extent of overlap between the various firms' diversity molecules remains unknown. A trusted intermediary accordingly would need access to structural data on a confidential basis in order to determine the degree of overlap. It could then release this information (in suitably anonymized fashion) to participating firms.

For example, in a situation where three firms had contributed molecular libraries, the intermediary might reveal that, of the total number of molecules contributed, about twenty percent were duplicates owned by two firms and ten percent by three firms. At that point, the participating firms would determine whether the degree of overlap was sufficiently small to justify going forward. If the firms decided to proceed, the pooled molecules would already have been collated and any instances of duplication identified. This collation would, in turn, eliminate duplicative screening.

\section{B. A Two-Tiered Regime}

Central to our proposed multi-firm partnership is a two-tiered system. At Tier 1, both academic external researchers and the participating companies could be viewed as operating behind a "veil of ignorance." ${ }^{.82}$ Although the researcher might possess some information about a potentially interesting assay, and the participating companies might hold some basic information about the molecules they contributed, information on both sides would be relatively inchoate and precompetitive in nature.

Equally important, only the trusted intermediary would know about the full set of assays and molecules existing at Tier 1. Individual academic researchers and contributing firms would remain unaware of contributions by any other parties. In contrast, research activities conducted at Tier 2, under the custom-made

82. Cf. John Rawls, A TheOry Of Justice (1971). 
contractual arrangements described below, would necessarily have moved beyond this veil of ignorance.

The trusted intermediary would host the pool and assume responsibilities for its day-to-day management and administration. The intermediary would also certify and perhaps fund the public-sector academics allowed to explore the molecules held in the pool. Additional financial guarantees from participating universities might become necessary in order to assure pharmaceutical firms that contractual obligations regarding nondisclosure were respected.

\section{Tier 1: Behind the Veil of Ignorance}

At the first tier of the partnership, researchers in approved academic institutions (that is, institutions that had signed nondisclosure agreements and perhaps put up a bond to guard against misappropriation) would contribute assays. The trusted intermediary would then run these assays against the pooled collection of small molecules made available by participating firms. All molecules contributed to the pool would be tagged with a marker that tracked their corporate origin. The trusted intermediary would, however, code these markers so that researchers receiving information on "hits" resulting from high-throughput screening would not know the pharmaceutical firm owner of the molecules they were using.

Successful high-throughput screening of these molecules would likely identify a subset of molecules as "hits"- in other words, molecules that showed significant activity against the target in question and could lead to new drug candidates. The academic who contributed the assay would receive coded results showing levels of activity for the relevant molecules, and the firms would receive some information as well. This Tier 1 information would be released in a structured way, in order to best facilitate the formation of an academic-pharmaceutical partnership for further target validation and drug development.

Prior to being told that one or more of the molecules it had contributed represented a hit, the firm could withdraw a molecule at any point. In order to forestall opportunistic behavior, however, once the trusted intermediary informed the firm that one of its molecules represented a hit, that molecule could not be withdrawn. On the contrary, after a hit, the contributing firm would have an obligation to provide relevant structural information to the academic via the intermediary. ${ }^{83}$ Standardized licenses governing first-tier access would forbid information disclosure or misappropriation.

For its part, the academic laboratory and associated university (communicat-

83. For purposes of collation and determining overlap, the firm would already have provided this structural information to the intermediary. As discussed further in the illustrative example below, see infra Section III.E, structural information is probably the primary information the firm would have. In particular, firms would be unlikely to contribute to the pool molecules about which they had significant positive information. 
ing through the intermediary) would provide the firms that owned hit molecules with a general statement of the methodology used to develop its target. However, in order to maintain its bargaining position despite the absence of a patent, ${ }^{84}$ the academic institution would not identify that target ${ }^{85}$ Therefore, at this point, the academic scientist would know the chemical structure of a number of compounds that showed activity against the target, while the pharmaceutical firm(s) would know that one or more molecules from their libraries had presented interesting research possibilities.

The public-sector scientist, with the assistance of the trusted intermediary, would attempt to determine which firm had the combination of hit molecules most likely to yield a successful drug. The decision would presumably be based on an assessment of liabilities and assets associated with the structures in question. Through the trusted intermediary, a firm could also, if it so desired, share with the scientist on a confidential basis any additional information that it might have. Presumably, it would do so in order to entice the scientist into a second-tier partnership.

A complication in the process would arise if one or more of the chosen firm's hit molecules were duplicates of molecules owned by another firm. In all likelihood, co-ownership of even one molecule should remain a relatively rare occurrence because, as discussed earlier, if molecules contributed by different firms overlapped significantly, there would be little reason to move forward with a multi-firm pool.

In the event of co-ownership, there are several options worth considering, and one to be avoided. The latter is the default route of future patent coownership (e.g., co-ownership of a patent on a potential lead compound that emerged from the co-owned molecule). Patent law encourages strategic behavior on the part of co-owners by allowing each one to "make, use, offer to sell, or sell the patented invention ... without the consent of and without accounting to the other owners. ${ }^{86}$ Although this default approach has the virtue of facilitating licensing (because the consent of only one co-owner is needed), it also means that disagreement between co-owners undermines the existence of an effective patent monopoly. Under our current system of R\&D financing, monopoly rights on drugs are critical for hedging the risk associated with the long and complex preclinical and clinical development process. ${ }^{87}$

84. University participants in the partnership would be barred from seeking patents on assays or targets prior to participation in the screening program. See infra Section IV.B.

85. For further discussion of the university perspective, as well as the perspectives of other stakeholders, see infra Part IV.

86. See 35 U.S.C. $\S 262$ (2000). See generally Robert P. Merges \& Lawrence A. Locke, CoOwnership of Patents: A Comparative and Economics View, 72 J. PAT. \& TRADEMARK OFF. SOC'Y 586 (1990) (discussing possibilities for opportunistic behavior created by the law of co-ownership).

87. See, e.g., Wesley M. Cohen et al., Protecting Their Intellectual Assets: Appropriability 
The simplest solution would allow the researcher to continue with the firm he or she had chosen, notwithstanding co-ownership of one or more hits. This option would be particularly useful if (as seems likely, given that the threshold inquiry would presumably have found relatively little overlap in contributions) only one or two molecules out of the chosen firm's set of hits were co-owned. The co-owner might then be entitled to royalty-based compensation if the molecule in question led to a marketable drug, but it would have avoided the cost and risk of follow-on work.

In the rare case where all (or most) of the relevant molecules were coowned, the co-owning firms could set up a separate joint venture that would hold future patent rights. In order to avoid antitrust concerns in cases where the joint venture occupied a large share of the relevant research space, one of the firms could remain a silent partner that simply held a pre-determined equity stake in the joint venture. Importantly, the initial framework agreement would specify the alternatives available in situations of dual ownership so as to rule out the possibility of co-ownership of patents.

As noted earlier, ${ }^{88}$ it appears that some pharmaceutical firms have already formed public-private partnerships with academic researchers whose published work indicates that they are working on interesting targets. They have done so, however, on a limited, ad hoc basis. Our first tier public-private partnership would provide a standardized platform for the systematic formation of many more second tier relationships than currently exist. Not only would the basis for forming such relationships be put in place, but with routine access to a pool of high-quality small molecule libraries guaranteed, one would also expect the public sector to develop many more validated targets that would be of interest to pharmaceutical companies.

Essentially, firms would be outsourcing assay development and target validation to individual academics who are well placed to do this work, but who would otherwise be difficult to integrate into the firm vertically as employees. ${ }^{89}$ As contrasted with vertical integration, a public-private partnership would allow assay developers to run their assays against a broad array of molecules held by multiple firms.

Conditions and Why U.S. Manufacturing Firms Patent (or Not), (Nat'l Bureau of Econ. Research, Working Paper No. 7552, 2000), available at http://www.nber.org/papers/w7552; cf. Tracy R. Lewis, Jerome H. Reichman \& Anthony D. So, The Case for Public Funding and Public Oversight of Clinical Trials, ECONOMISTS' VOICE, Jan. 2007, http://www.bepress.com/ev/vol4/iss1/art3/ (arguing that clinical trials should be treated as a public good).

88. See supra note 41 and accompanying text.

89. Cf. Bemard Munos, Can Open-Source R\&D Reinvigorate Drug Research?, 5 NATURE REVS. DRUG DISCOVERY 723, 723 (2006) (discussing the outsourcing of drug research-related laboratory and clinical studies "to institutions with the requisite capacity through the help of matchmaking software"). 


\section{Tier 2: Beyond the Veil of Ignorance}

Once the academic had chosen a prospective partner, second-tier negotiations would commence. Because the terms of such second-tier partnerships are likely to vary quite substantially depending on the type of target at issue, we do not propose standard-form agreements for this tier. Presumably, the negotiated contract enabling Tier 2 research would further specify the expected relations of the parties during the drug development phase, and the distribution of expected royalties from patented lead compounds. Assuming the drug development process proved successful, and the patented drug passed clinical trials and entered the stream of commerce, the patent owner (i.e., the pharmaceutical firm) would obtain patent rents exactly as occurs at present.

A possible complication could arise, however, if the scientist and the pharmaceutical firm could not successfully conclude a second-tier agreement. In that case, we would propose that the scientist retain the opportunity to negotiate with the owners of other molecules that had represented hits at Tier 1 . The information obtained by the academic in the negotiations with the first firm would, of course, remain subject to confidentiality and nondisclosure agreements.

If a Tier 2 partnership was formed and subsequently dissolved, the magnitude of potential inter-firm information leakage could become sufficiently great as to rule out allowing the scientist to negotiate with other firms. In any event, the framework agreement for the partnership would have to provide for both of these contingencies.

An important question to be addressed in the Tier 2 agreement would concern the timing of any eventual publication by the academic. Although we do not propose standard form agreements at Tier 2, the framework agreement should ensure that the academic can publish his or her findings as soon as appropriate arrangements for patentability had been made. This would represent an improvement over the current situation, where the available empirical evidence indicates that corporate sponsors sometimes require academics to withhold data well beyond the time necessary to file a patent. ${ }^{90}$

\section{The Option of a Contractually-Constructed Liability Regime $e^{91}$}

In addition to the structure outlined above, participating firms might also

90. See, e.g., David Blumenthal et al., Relationships Between Academic Institutions and Industry in the Life Sciences-An Industry Study, 334 NEw ENG. J. MED. 368, 371 (1996) (finding that fifty-six percent of corporate sponsors report that research results are sometimes kept confidential longer than the time required to file a patent).

91. The term "contractually-constructed liability regime" is drawn from J.H. Reichman \& Paul F. Uhlir, A Contractually Reconstructed Research Commons for Scientific Data in a Highly Protectionist Intellectual Property Environment, 66 LAW \& CONTEMP. PROBS. 315 (2003). 
agree on a supplementary system of royalties that would govern compensation to any firm that had provided structural information about its molecules to a researcher deciding among promising "hits." In other words, firms would be contracting into a subsidiary set of "take and pay rules," or liability rules, rather than relying entirely on exclusive property rights. ${ }^{92}$ As a historical matter, liability rules have always modulated between exclusive property rights, on the one hand, and the public domain, on the other. ${ }^{93}$ In modern times, codified liability regimes that provide ex ante entitlements to compensation for certain uses (but not necessarily a right to exclude others from use) have been adopted in some intellectual property systems, ${ }^{94}$ and in at least one international treaty. ${ }^{95}$

One feature of liability rules is that, even in the absence of legislative fiat, they may be voluntarily adopted whenever stakeholders seek to obtain a private ordering with outcomes that differ from what the default rules of intellectual property law might otherwise provide. ${ }^{96}$ For example, various commentators have discussed patent pools as an example of contractually-constructed liability rules. ${ }^{97}$ Similarly, contractually-constructed liability rules are sometimes used by

92. The classic reference is, of course, Guido Calabresi \& Douglas Melamed, Property Rules, Liability Rules, and Inalienability: One View of the Cathedral, 85 HARV. L. REV. 1089 (1972); see also Robert Merges, Contracting into Liability Rules: Intellectual Property Rights and Collective Rights Organizations, 84 CAL. L. REv. 1293 (1996).

93. See, e.g., J.H. Reichman, Saving the Patent Law from Itself: Informal Remarks Concerning the Systemic Problems Affecting Developed Intellectual Property Regimes, in PERSPECTIVES ON Properties of the Human Genome Project 289 (F. Scott Kieff ed., 2003).

94. See, e.g., J.H. Reichman, Charting the Collapse of the Patent-Copyright Dichotomy, 13 CARDOZO ARTS \& ENT. L.J. 475, 504-20 (1995) (stressing the need for a new intellectual property paradigm based on liability rules for cumulative and sequential innovation); J.H. Reichman, Legal Hybrids Between the Patent and Copyright Paradigms, 94 COLUM. L. REv. 2432, 2477 (1994) (discussing an Italian regime protecting construction designs and technical drawings); id. at 2480 (discussing the British Design Law of 1988, since repealed by the E.U. Design Regulation); see also Merges, supra note 92 , at 1308-09 (discussing 17 U.S.C. $\$ 115$, a liability regime for sound recordings of copyrighted musical works).

95. F.A.O. Res 3/2001, International Treaty on Plant Genetic Resources for Food and Agriculture, Nov. 3, 2001, http://www.fao.org/ag/cgrfa/itpgr.htm (imposing a compensatory liability regime on those who make commercial applications derived from public-domain seeds).

96. See J.H. Reichman, Of Green Tulips and Legal Kudzu: Repackaging Rights in Subpatentable Innovation, 53 VAND. L. REV. 1743 (2000); see also Jerome H. Reichman \& Tracy Lewis, Using Liability Rules To Stimulate Innovation in Developing Countries: Application to Traditional Knowledge, in INTERNATIONAL PUBliC GOOdS AND TRANSFER OF TECHNOLOGY UNDER a Globalized InTEllectual Property Regime 337 (Keith E. Maskus \& Jerome H. Reichman eds., 2005).

97. See, e.g., Merges, supra note 92, at 1340-52. As Merges discusses, the typical patent pool involves multiple firms agreeing voluntarily to refrain from exercising their rights to exclude. Instead of asserting patent rights, firms contribute the rights to a package license that is available on 
patent holders as a mechanism for generating revenue from background property rights. (Indeed, proponents of the "one monopoly profit" thesis would argue that patent holders should generally be indifferent between using liability rules and exploiting their monopoly exclusively. $)^{98}$ When Stanford University famously made its Cohen-Boyer patent on DNA manipulation techniques available to all users willing to pay specified royalties under a non-exclusive license, it voluntarily converted the exclusive rights conferred by its patent to a liability regime. ${ }^{99}$

As discussed further below, ${ }^{100}$ we believe the possibility of a liability rule payment could induce greater participation by pharmaceutical firms. This compensatory liability payment (say, on the order of three to five percent) would become available to firms if any of their molecules fell within the class of promising "hits" at the initial stage of high-throughput screening. Firms would accordingly benefit from income streams not only in circumstances where they actually undertook the expensive and risky follow-on work that led to a patented marketable drug, but also if they contributed a small amount (in the form of structural information on a hit) to upstream work. In this manner, firms could, to some extent, mitigate the overall risks of drug development. ${ }^{101}$

The framework agreement for our proposed partnership would spell out any ex ante liability rule entitlements that the participating firms had agreed to adopt. The intermediary would also collect and share data concerning the impact of the liability regime as a cost-sharing and risk-reducing technique over time. However, in the event that such obligations triggered antitrust difficulties or deterred participation (perhaps because firms doing the follow-on work resisted the liability rule as an unacceptable "reach-through royalty"), ${ }^{102}$ they remain an optional feature of our proposal.

reasonable terms either to participants in the pool or to all comers. Id. In recent years, the pooling of patents around information technology industry standards has become quite common. See, e.g., Carl Shapiro, Navigating the Patent Thicket: Cross-Licenses, Patent Pools, and Standard Setting, in 1 InNOVATION POLICY AND THE ECONOMY 119 (Adam Jaffe et al. eds., 2001).

98. For an excellent discussion of the implications of the "one monopoly profit" thesis for platform technologies, and of situations where the thesis might not apply, see Joseph Farrell \& Philip Weiser, Modularity, Vertical Integration, and Open Access Policies: Towards a Convergency of Antitrust and Regulation in the Internet Age, 17 HARV. J.L. \& TECH. 85, 104, 105-19 (2003).

99. For a discussion of the Cohen-Boyer licensing strategy, see Rai \& Eisenberg, supra note 45 , at 300 .

100. See infra Section IV.A.

101. We also believe that the innovation-related benefits of a liability rule scheme (in terms of inducing participation in the pool) are sufficiently large that a small royalty paid to competitors should not be deemed to violate antitrust law. See infra Section IV.D.

102. See supra note 38 . 


\section{Adding New Participants}

The public-private partnership we propose would be most likely to succeed if the founding members were firms with robust libraries that continued to be active in the search for new targets. At the same time, it would be inopportune, counterproductive, and possibly illegal as a matter of antitrust law to foreclose the possibility that other firms might join the pool. The pool members would thus be well-advised to organize from the outset the conditions of future membership.

Because of the manner in which the pool would be structured-specifically, the fact that private-firm researchers would not have any access to the small molecule pool and that even access by academic researchers at Tier 1 would be restricted to information about potentially promising "hits" — adding additional members should be relatively straightforward. New members and their contributions would be protected by the same nondisclosure agreements as pre-existing members. Similarly, hit molecules contributed by new members would be treated in the same manner as hit molecules contributed by founding members.

Notably, existing consortia, such as the PSTC, explicitly provide for the addition of new members. Under the PSTC framework agreement, new members that can contribute to biomarker validation and pay membership fees are allowed into the consortium as a matter of course. ${ }^{103}$

\section{E. An Illustrative Example}

Consider the following stylized example of the manner in which our proposed public-private partnership would work. ${ }^{104}$ Many researchers believe that Alzheimer's disease is caused by the accumulation of short protein fragments that are formed when certain precursor proteins (known as amyloid precursor proteins) break down. ${ }^{105}$ An Alzheimer's researcher (Researcher A) in University $B$ determines that a previously unknown protein (protein $C$ ) appears to be centrally involved in the breakdown of amyloid precursor proteins. She creates an assay designed to test whether a small molecule binds to protein $\mathrm{C}$ ("protein $\mathrm{C}$ binding assay").

Researcher A (and her employer, University B) have previously complied with all the requirements for participation in the screening pool. She and her university have signed the relevant nondisclosure agreements and have posted the bond necessary to reinforce the pertinent nondisclosure rules. Thus, she is eligi-

103. Consortium Agreement, supra note 68, $\$ 3.3$.

104. Note that although the facts in this example are generally based on accurate scientific information, they are intended for illustrative purposes only.

105. See, e.g., Vincent T. Marchesi, An Alternative Interpretation of the Amyloid A $\beta$ Hypothesis with Regard to the Pathogenesis of Alzheimer's Disease, 102 PROC. NAT'L ACAD. SCI. 9093, 9093 (2005). 
ble to submit her assay to the trusted intermediary who will screen it against the aggregate collection of molecules that Companies 1, 2, and 3 have contributed to the pool.

The trusted intermediary will have previously compared the structure of the molecules submitted by these companies and presumably found only a small amount of overlap (e.g., only ten percent of molecules were owned by two firms and one percent were owned by three firms). Based on this small amount of overlap, the companies had decided to go forward with the pool.

The trusted intermediary proceeds to screen the combined molecule libraries of all three companies against the protein $\mathrm{C}$ binding assay. The intermediary then gives the results, which include the raw data generated in the experiment, to Researcher A. In consultation with the trusted intermediary, Researcher A determines that there is a group of seven molecules that show significant activity and might lead to promising new drugs. The trusted intermediary informs A that these molecules are owned by Companies 1 and 3-Company 1 owns three of the molecules, and Company 3 owns the other four.

At this point, the trusted intermediary also informs Companies 1 and 3 that they have molecules that represent hits, but the companies do not learn that they are hits on protein $C$ specifically. Companies 1 and 3 can no longer withdraw the relevant molecules from the pool, and they must provide Researcher A with information about the structures of the hit molecules. Researcher A and the trusted intermediary analyze the structures they have been given and the results of the assay, and on that basis decide that Researcher A and University B should attempt to negotiate a Tier 2 agreement with Company 3 . If an agreement is reached with Company 3 , and subsequently results in a new drug, Company 1 may be entitled to a three to five percent royalty as provided for in the framework agreement. If the negotiations with Company 3 fail, Researcher A and University $B$ have the option of negotiating with Company 1.

In the more complex case where one or a few of the molecules in Company 3 's set of hits is also owned by another company (say Company 2), the decisionmaking process would be governed by the rules upon which the stakeholders had previously agreed. For example, the framework agreement might provide that in most cases, Researcher A could simply continue working with Company 3 , while Company 2 might become entitled to some predetermined compensation but would not participate in, or bear any risk associated with, downstream research. In the rare case that the relevant molecules were all co-owned, the framework agreement might enable Companies 2 and 3 to form a joint venture that owned any resulting patent rights. ${ }^{106}$

106. The possibility of using joint ventures in downstream work on a set of promising molecules drawn from different sources would depend on the attitude of the relevant antitrust authorities. We discuss the antitrust implications of these options below. See infra Section IV.D. 
If this and similar ventures were to succeed, the framework agreement would have maximized opportunities to generate new drugs by multiplying the number of assays that were screened against an expanded chemical space. In this manner, our model would enable complex and risky research that might not otherwise have occurred under existing arrangements. More importantly, it could enable and greatly increase the likelihood of breakthrough therapeutic results on significant diseases.

\section{F. Single Firm Public-Private Partnerships}

As previously observed, even if the trusted intermediary determined that the molecules that firms had contributed overlapped substantially, it would still be in the firms' interest to undertake some sort of collaborative approach. In that case, however, a better approach might rely on one or more single firm public-private partnerships. A single-firm partnership would give academic researchers the opportunity to screen their assays against that portion of the firm's library that the firm chose to make available.

Single firm public-private partnerships would not require the level of organizational infrastructure required by a broader pooling approach. A willing firm might simply invite interested academic researchers to submit assays, which it would then screen in-house against some subset of compounds within its proprietary library. However, a trusted intermediary might remain useful in this context, especially if it could assist the firms in identifying potential academic research participants and their associated institutions.

For example, in the context of tropical diseases targets, it appears that the World Health Organization's (WHO) Tropical Disease Network has organized a consortium of researchers who are interested in screening their targets against pharmaceutical firm libraries. Three firms-Pfizer, Merck Serono, and Chemtura-are now allowing this "TDR Compound Evaluation Network" to submit targets for in-house screening against a subset of the firms' respective chemical libraries. ${ }^{107}$ The trusted intermediary might also help to fund the academic scientists, guard against misappropriation of unpatented results by participants in the partnership, and set the conditions of eventual publication of research results.

Because the "private" side of the partnership would, at any given time, be limited to a single firm, there would be no need for a two-tiered regime. Rather, qualified academics would simply submit assays to the firm in question. If and when a particular screening assay yielded a group of hits, the academic and the firm would then negotiate the terms of a public-private development partnership. As with the multi-firm partnership, the private firm would be free to withdraw molecules from the screening process up to the point when the molecule yielded a hit.

107. Hopkins, Witty \& Nwaka, supra note 67, at 169. 
In the event that screening against the library of a given firm yielded no interesting hits, the academic investigator might want to submit the assay to other firms that had made a subset of their libraries available. However, because anonymity could not be preserved in a single-firm arrangement, "sequential" screening would depend on the first firm's willingness to permit it.

\section{ANALYZING THE COLLABORATION: STAKEHOLDER INCENTIVES AND TRADEOFFS}

Having outlined the basic principles of our two-tiered proposal, we turn to a detailed discussion of the incentives that would induce stakeholders to enter into such an arrangement. We also briefly discuss salient antitrust issues pertinent to our proposal.

\section{A. The Firms' Perspective}

Pharmaceutical firms stand to gain a great deal, and lose little, through participation in our proposal. Current efforts to generate truly novel drugs are failing. Our proposal would leverage the expertise of publicly funded researchers in a manner that redounds to the benefit of the pharmaceutical industry as a whole while limiting aggregate costs and generating considerable efficiencies in the upstream research process.

Firms will be concerned about the risk that potentially important trade secret information (specifically, molecular structure and the fact that a particular molecule shows activity against an assay) might leak over to competitors. For this reason, only academic researchers should be allowed access to such information. Those researchers who identified a promising molecule would be deterred from misappropriation not only by contractual obligations and required bonding, but also by their need to partner with the firm contributing the most promising molecule in order to commercialize the research results.

By contrast, allowing private-sector researchers entry into the pool would create undue risk of misappropriation and industrial espionage. Fear of such misappropriation might deter firms from entering the pool in the first instance. Alternatively, firms might be tempted to contribute only "bad" molecules. Indeed, fear of misappropriation is so great that various efforts to foster even a limited amount of inter-firm information exchange about molecular library contents in the past have foundered on the inability of firms to sufficiently disguise or "mask" information about molecular structure. ${ }^{108}$ Restricting participation to aca-

108. See Elizabeth K. Wilson, Is Safe Exchange of Data Possible? Modelers in Need of Proprietary Compounds Seek Ways To Share Information, But Not Structure, CHEMICAL \& ENGINEERING NEWS, Apr. 25, 2005, at 24, available at http://pubs.acs.org/cen/science/83/8317scil html (describing efforts to enable "safe exchange" of chemical structures). 
demic scientists - a prominent feature of our proposal-should prove attractive from the firms' perspective.

Moreover, even with respect to academic researchers, access to molecules would remain quite limited. The trusted intermediary would conduct the highthroughput screening on submitted assays. At Tier 1, academic researchers would receive results (and accompanying structural information) only with respect to molecules that represented hits. In exchange for this information, firms would be rewarded with the possibility of a collaboration as well as a potential royalty even if their firm was not chosen to undertake downstream development.

However, leakage of some structural information between firms might occur in certain circumstances, namely, when an assay revealed hit molecules from two different firms. If an academic moved on to a Tier 2 collaboration with one firm, there is some concern that he might inappropriately use information about the other firm's molecule(s). Similarly, if Tier 2 negotiations with one firm fell through, the researcher might take information derived from those negotiations into conversations with a second firm.

To forestall these possibilities, the framework agreement for the partnership should explicitly prohibit researchers from using information derived from one firm in their dealings with another firm. Enforcement of such a provision might prove difficult, however. Thus, the firm that was not chosen might be best rewarded for the risk of some level of leakage through the contractuallyconstructed liability scheme discussed above. ${ }^{109}$

\section{B. The Academic Researchers' Perspective}

Researchers, and their universities, should be motivated to participate in the collaboration through financial incentives and the potential for groundbreaking discoveries. If academic researchers succeeded in validating a target, they, and their universities, would find themselves in a strong position to negotiate a favorable Tier 2 agreement with one of the companies contributing hit molecules.

The academics would bring to the table their substantial knowledge of the assay and target, and the pharmaceutical firm would bring its information concerning the relevant molecule, its expertise in medicinal chemistry, as well as all of its downstream development resources. If the resulting partnership yielded a commercially successful drug, the researcher and his university would secure a share of the revenues. ${ }^{110}$ They would also secure a reputational gain through

109. See supra Section III.C.

110. Note that this is a different claim from the argument that technology licensing (e.g., patent licensing) is likely to bring in substantial revenue. As many observers have noted, university patent licensing generally involves upstream technology with uncertain payoffs and therefore revenues are typically quite small. Only in the relatively unusual circumstance where the university sells rights to a drug is the revenue payoff substantial. See, e.g., Press Release, Emory University, Gilead Sci- 
eventual publication of the breakthrough research.

In our view, these financial and reputational benefits to the public research community should help to offset delays in publication that participating firms might deem necessary to protect commercially valuable information. Specifically, as noted earlier, the researcher exploring chemical space at Tier 1 would have to sign a nondisclosure agreement with respect to any structural data on molecules that he or she received. ${ }^{111}$ Additionally, at Tier 2, the researcher must be willing to forego publication of commercially valuable information until relevant patents (e.g., on promising lead compounds) had been filed.

The ultimate financial benefits should also mitigate certain limitations on university patenting that are likely corollaries of our proposed public-private partnership. Under current law, universities are entitled to seek intermediate patents on validated targets. In the proposed collaboration, universities would forgo such patents in exchange for a transactional commitment at Tier 2 by the pharmaceutical company to a revenue stream from any drug that was ultimately developed. This revenue stream would recognize the significant research contribution of the university and its researcher.

\section{The Perspective of the Trusted Intermediary}

In order for the proposed public-private partnership to take off, the trusted intermediary would probably have to provide some seed funding. Specifically, the intermediary might, at least initially, bear the cost of funding researchers to develop assays, of conducting high-throughput screening, and of general pool administration. However, once the concept of pooling small molecule libraries had proved to be scientifically and economically viable, the firms themselves should be willing to subsidize many, if not all, of the activities in the collaboration.

If the trusted intermediary were the NIH, or an NIH-funded proxy, our proposal could be seen as complementary to its Molecular Libraries Initiative. While the MLI is likely to prove very useful in advancing basic knowledge about biological pathways, lack of access to small molecule libraries held by pharmaceutical firms may limit its success in target validation. At a minimum, the MLI will not typically result in potential lead compounds. More generally, two of the three themes highlighted in the current NIH Roadmap for Medical Researchencouraging "new pathways for discovery" and supporting "research teams of the

ence and Royalty Pharma Announces \$525 Million Agreement with Emory University To Purchase Royalty Interest for Emtricitabine (July 18, 2005), available at http://www.news.emory.edu/ Releases/emtri/ (describing payment of $\$ 525$ million for sale of royalty rights to anti-AIDS drug). Our proposal similarly would involve partnerships dealing with end-product drugs; therefore, revenue payoffs could be substantial.

111. See supra Subsection III.A.2. 
future,"112 (including interdisciplinary work and public-private partnerships)are specifically promoted by the terms of our proposal.

The pharmaceutical companies could, of course, foot the bill for the entire initiative and establish their own trusted intermediary. We believe, however, that participation of a public entity remains desirable, even if the operation were totally funded by the private sector. For example, the presence of a public-sector player would greatly simplify relations with academia and add a layer of indirect enforcement of nondisclosure rules that would reassure the participating firms. Likewise, a public sector presence would reinforce the academic scientists' expectations that the public interest in shared research results would ultimately be respected, without compromising either side's intellectual property rights. Finally, the presence of a public-sector player would greatly facilitate negotiations between the trusted intermediary and the antitrust authorities over time.

\section{Antitrust Concerns and the Public Interest}

If successful, our proposal would necessarily entail some level of collaboration between firms that represent a significant percentage of the pharmaceutical industry. For the most part, only limited inter-firm R\&D coordination or exchange of information would occur-largely confined to contexts where complementary assets had to be deployed in order to maximize research potential. Thus, we believe that our proposal should pass muster from the standpoint of both normative economic analysis and antitrust doctrine.

The question of whether a competitive or concentrated (perhaps even monopolistic) market structure best promotes innovation has long been mooted in the economic literature. Joseph Schumpeter famously argued that concentration promotes risky innovation by allowing firms to limit diffusion of knowledge to competitors and thus appropriate more fully the benefits of their innovative efforts. ${ }^{113}$ In contrast, Kenneth Arrow and others have asserted that monopoly power can dull incentives to innovate, particularly in situations where a new product would displace a product already produced by the monopolist. ${ }^{114}$

As antitrust doctrine has expanded its focus beyond end product markets, it too has examined the relationship between competition and innovation. Influenced by Arrow's work, in the mid-1990's the Federal Trade Commission (FTC) and the Antitrust Division of the Department of Justice (DOJ) adopted an "innovation markets" analysis, which looks at competition in the R\&D processes that

112. NAT'L INSTS. OF HEALTH, NIH ROADMAP FOR RESEARCH (2006), http://nihroadmap.nih.gov/ pdf/NIHRoadmap-FactSheet-Aug06.pdf.

113. See Joseph A. SCHUMPETER, CAPITALISM, SOCIALISM AND DEMOCRACY 81-106 (1942).

114. See, e.g., Arrow, supra note 32. For a summary of these arguments, see Rai, supra note 26, at 824-25. 
produce end products. ${ }^{115}$ Under innovation markets analysis, a joint venture, licensing agreement, or merger is suspect if it unduly limits the number of competing innovators and yields no offsetting innovation-related efficiencies.

Although innovation markets analysis might imply a relatively strict review of R\&D collaborations, the DOJ and FTC have emphasized how difficult it is to define an innovation market. ${ }^{116}$ In practice, the overriding focus in most cases is not market definition but whether the collaboration is likely to accelerate or slow the pace at which R\&D efforts are pursued. ${ }^{117}$ The agencies specifically recognize that "[t]hrough the combination of complementary assets, technology, or know how, an R\&D collaboration may enable participants more quickly or more efficiently to research and develop new or improved goods ...."118

In the case of our proposed collaboration, the reality that $R \& D$ on new drug targets is very expensive and risky should make antitrust authorities more disposed towards a Schumpeterian perspective on the resulting pharmaceutical innovation. Nonetheless, two aspects of our model might concern antitrust regulators. First, the optional liability rule scheme we have proposed might be seen as a reach-through royalty that dulled incentives on the part of the firm enjoying the royalty to innovate independently. However, we think it is unlikely that a small royalty stream would significantly affect such incentives. The situation where no one works on a molecule that modulates a new target is much more likely. Indeed, it is the status quo.

The second antitrust difficulty might involve the situation where coownership of molecules required a substantial compensatory royalty or even a joint venture. In both cases, the argument in favor of allowing collaboration would rest on the fact that the assets in question were co-owned and therefore complementary.

To address antitrust concerns expeditiously, we would propose that the initial framework agreement expressly address questions of co-ownership (and, if desired, liability rules), and that this agreement be vetted by the antitrust authorities before any collaborative work began. The PSTC framework agreement pro-

115. Dep't of Justice \& Fed. Trade Comm'n, Antitrust Guidelines for the Licensing of INTEllectual Property $\& 3.2 .3$ (1995) [hereinafter DOJ, InTEl LeCtual Property], available at http://www.usdoj.gov/atr/public/guidelines/0558.htm (defining innovation markets); see also DEP'T of Justice \& Fed. TRade Comm'N, Antitrust Guidelines for Collaborations among COMPETITORS $\S 3.32(\mathrm{c}) \quad(2000)$ [hereinafter DOJ, COLlaBORATION], available at http://www.ftc.gov/os/2000/04/ftcdojguidelines.pdf (discussing innovation markets).

116. "The Agencies will delineate an innovation market only when the capabilities to engage in the relevant research and development can be associated with specialized assets or characteristics of specific firms." DOJ, INTEllectual Property, supra note $115, \S 3.2 .3$; see also DOJ, COLlabORATION, supra note $115, \S 3.32$ (c).

117. DOJ, Collaboration, supra note $115, \S 3.31$ (a).

118. Id. 
vides an instructive example. It contains an "antitrust statement" that limits interfirm sharing of information to that necessary for purposes of biomarker validation and allows consortium members to pursue independent biomarker validation projects. ${ }^{119}$ We would envision a similar statement addressing antitrust concerns in our framework agreement.

\section{CONCLUSION: BROADER IMPLICATIONS OF THE COLLABORATIVE APPROACH}

In developing our proposal for greater access to small molecule libraries, we have drawn upon models of inter-firm collaboration that the pharmaceutical industry is currently using for biomarkers. However, our approach is designed to work in settings different from the creation of biomarker standards, where rights in collaborative outputs must be tightly protected.

For example, a similar approach may be useful in advanced materials engineering research. Such research represents a context where inter-firm transfer of inchoate and unpatented, but nonetheless valuable, information is desirable. ${ }^{120}$ Contract-based exchange can be implemented so long as the connection between the inchoate information put in ex ante and the codified, differentiated information that emerges ex post is reasonably clear. The presence of a trusted intermediary that polices contract breaches and prevents undesirable spillovers is also important.

Our proposal attempts to embody all the features that are likely to facilitate contract-based exchanges of pre-patentable, but nonetheless valuable, information. If academics and pharmaceutical firms are interested in truly innovative drug discovery, they should experiment with this effort to forge new and viable pathways across what has hitherto proved to be a largely impassable "valley of death."

119. See Consortium Agreement, supra note 68, at exhibit A.

120. Professor Krishna Rajan, Iowa State University, Presentation at the University of Tokyo Conference on Designing Global Information Commons for Innovation in Frontier Sciences (Nov. 8,2007 ) (conference notes on file with authors). 